\title{
Cold atmospheric plasma inhibits the growth of osteosarcoma cells by inducing apoptosis, independent of the device used
}

\author{
LYUBOMIR HARALAMBIEV $V^{1,2^{*}}$, LASSE WIEN $^{1 *}$, NADINE GELBRICH $^{3}$, \\ JÖRN LANGE ${ }^{1}$, SINAN BAKIR ${ }^{1,2}$, AXEL KRAMER $^{4}$, MARTIN BURCHARDT $^{3}$, \\ AXEL EKKERNKAMP ${ }^{1,2}$, DENIS GÜMBEL ${ }^{1,2}$ and MATTHIAS B. STOPE ${ }^{3}$ \\ ${ }^{1}$ Department of Trauma, Reconstructive Surgery and Rehabilitation Medicine, \\ University Medicine Greifswald, D-17475 Greifswald; ${ }^{2}$ Department of Trauma and Orthopaedic Surgery, \\ BG Klinikum Unfallkrankenhaus Berlin gGmbH, D-12683 Berlin; ${ }^{3}$ Department of Urology; ${ }^{4}$ Institute of Hygiene and \\ Environmental Medicine, University Medicine Greifswald, D-17475 Greifswald, Germany
}

Received April 4, 2019; Accepted October 11, 2019

DOI: $10.3892 /$ ol.2019.11115

\begin{abstract}
Osteosarcoma (OS) is the most common tumor of the musculoskeletal system. Recently, cold atmospheric plasma (CAP) has been regarded as a promising anti-oncogenic therapy. Previous experimental studies have demonstrated that CAP treatment results in significant growth inhibition of human sarcoma and is able to induce apoptosis. However, due to device-specific parameters, there is a large variability in the antitumor effects of different CAP sources. In the present study, the cellular effects of CAP treatment from two different CAP devices were investigated and their pro-apoptotic efficacy was characterized. The OS cell lines, U2-OS and MNNG/HOS, were treated with two CAP devices, kINPen MED and MiniJet-R. Control groups were treated with argon. The anti-proliferative effect of each treatment was demonstrated using cell counting and the activation of apoptotic mechanisms was determined using Comet, TUNEL and Caspase-3/Caspase-7 assays. The results revealed that treatment of both OS cell lines with the two CAP sources resulted in significant inhibition of cell growth. Subsequently, the activation of Caspases and the induction of apoptotic DNA fragmentation was demonstrated. The biological effects of each CAP source did not differ significantly. The treatment of OS cells with CAP lead to an induction of apoptosis and a reduction of cell growth. Therefore, the biological effects of CAP appear to be general as the two devices of different design produced highly comparable cell responses. Therefore,
\end{abstract}

Correspondence to: Dr Lyubomir Haralambiev, Department of Trauma, Reconstructive Surgery and Rehabilitation Medicine, University Medicine Greifswald, Ferdinand Sauerbruch Straße 1, D-17475 Greifswald, Germany

E-mail: lyubomir.haralambiev@uni-greifswald.de

*Contributed equally

Key words: apoptosis, cold atmospheric plasma, osteosarcoma the type of device used does not seem to affect the efficacy of CAP-based antitumor therapy.

\section{Introduction}

Osteosarcoma (OS) is the most common primary malignant bone tumor in children and adolescents with a pronounced tendency for local invasion and early systemic metastases (1-3). OS also occurs in the connective tissue of the human skeletal system and originates from mesenchymal stem cells with osteogenic potential (4). The incidence of OS is higher in children and adolescents with rapid bone growth or in individuals between 10-25 years of age, accounting for $70 \%$ of all cases of OS (5). Although OS may develop in any bone, it frequently occurs in the femur and tibia, humerus, pelvis, jaw, fibula and ribs (6). The knee joint is the most frequently affected area, accounting for $50 \%$ of all cases (7).

OS has highly invasive metastatic properties, particularly in primary or postoperative haematogenic metastases, and as such, has a poor prognosis (8). OS therapy includes surgery, chemotherapy (cisplatin, doxorubicin and methotrexate) and radiotherapy $(9,10)$. Statistically, $\sim 85 \%$ of patients with OS exhibit metastases (11). The 2-year survival rate of patients with OS is $15-20 \%$ and the 5-year survival rate of metastatic patients is $5-20 \%(12,13)$.

Cold atmospheric plasma (CAP) is a highly energized gas $\left(\leq 40^{\circ} \mathrm{C}\right)$ consisting of numerous biologically active species, including reactive oxygen and nitrogen species $(14,15)$. Recent experimental studies have elucidated the inhibitory effect of CAP on tumor cells of various entities $(16,17)$. In vitro oncological CAP treatment has been demonstrated to significantly inhibit growth and induce apoptosis in cancer cells, particularly in OS cell lines (18). At the cellular level, CAP treatment leads to the activation of redox signaling pathways (peroxiredoxins), followed by the activation of p53-dependent apoptosis $(15,18,19)$. Furthermore, CAP treatment leads to the reduction of cell motility (20-24) and alterations of secretion patterns (25). Therefore, CAP may be a complementary treatment option for patients with OS, particularly in cases of insufficient tumor resectability. A previous study has revealed 
that the effect of CAP depends not only on the tumor cells affected, but also on the CAP devices used (22). Therefore, the present study examined the apoptotic effects of CAP treatment from two CAP sources.

\section{Materials and methods}

Cell culture. Human OS cell lines, U2-OS and MNNG/HOS (American Type Culture Collection), were cultured in DMEM containing $1.0 \mathrm{~g} / 1$ glucose supplemented with $10 \%$ FBS, $1 \mathrm{mM}$ sodium pyruvate and $1 \%$ penicillin/streptomycin (all purchased from PAN Biotech $\mathrm{GmbH}$ ) in a humidified atmosphere with $5 \% \mathrm{CO}_{2}$ at $37^{\circ} \mathrm{C}$. A total of $4 \times 10^{6}$ cells were seeded on an uncoated cell culture plate. Following incubation for 4 days, cells were washed twice in PBS, detached using $0.1 \%$ trypsin/0.04\% EDTA and resuspended in DMEM.

CAP treatment. In the present study, two CAP jet devices were used: kINPen MED (neoplas $\mathrm{GmbH}$ ), gas flow, $31 / \mathrm{min}$; supply voltage, $65 \mathrm{~V}$ direct current; frequency, $1.1 \mathrm{MHz}$; and MiniJet-R (Heuermann HF-Technik GmbH); gas flow, $1.4 \mathrm{l} / \mathrm{min}$; frequency, microwave resonator at $2.45 \mathrm{GHz}$. Both used argon as the carrier gas.

CAP treatment of U2-OS and MNNG/HOS cells was performed with the cells in suspension. A total of $5 \times 10^{5}$ cells in $200 \mu \mathrm{l}$ cell culture medium were placed in a 24-well culture plate and treated with CAP for the indicated times (U2-OS for $10 \mathrm{sec}$ and MNNG/HOS for $20 \mathrm{sec}$.). The resulting turbulence in the cell suspension ensured that each cell came into contact with the CAP jet and that the CAP treated medium was also uniformly dispersed. During treatment, a distance of $0.5 \mathrm{~cm}$ between the CAP jet and the surface of the cell suspension was maintained. By moving the handle of the CAP source evenly back and forth, additional mixing was achieved. After CAP exposure, the cell suspension was transferred into a fresh 24-well cell culture plate with $800 \mu 1$ cell culture medium. Samples were then incubated as described above.

CAP treatment of U2-OS cells $\left(5 \times 10^{5}\right)$ in $500 \mu$ l DMEM suspension was performed for $10 \mathrm{sec}$ following a meandering pattern. With regards to the comparable biological effects of CAP, treatment of MNNG/HOS cells $\left(5 \times 10^{5}\right)$ was performed for $20 \mathrm{sec}$ to achieve a consistent inhibition of cell proliferation in each cell line. A total of $5 \times 10^{5}$ (U2-OS) or $5 \times 10^{5}$ (MNNG/HOS) cells were suspended in $500 \mu \mathrm{l}$ DMEM and treated for $30 \mathrm{sec}$ in suspension following a meandering pattern.

After CAP treatment, cells were immediately transferred to poly-L-lysine (PAN Biotech $\mathrm{GmbH}$ )-coated 24-well cell culture plates and incubated in DMEM in a humidified atmosphere with $5 \% \mathrm{CO}_{2}$ at $37^{\circ} \mathrm{C}$.

For controls, $5 \times 10^{5}$ cells were suspended in $500 \mu 1$ DMEM and treated with argon for the same duration as CAP treatment. After control treatment, cells were transferred and incubated as described for the CAP-treated cells.

Proliferation assay. Growth of CAP-treated cells was examined using a CASY Cell Counter and Analyzer Model TT (Roche Applied Science) and compared with the control. Each cell line was seeded in $24-w e l l$ cell culture plates $\left(5 \times 10^{5}\right.$ cells $)$ and treated as indicated. The number of living cells was determined by trypsin/EDTA detachment of adherent cells and subsequent analysis of the cell suspension utilizing the CASY Cell Counter and Analyzer Model TT (Roche Applied Science). $100 \mu 1$ of the cell suspension was diluted in $10 \mathrm{ml}$ CASYton (Roche Applied Science) and analysis of a $400 \mu \mathrm{l}$ sample was performed in triplicate using a capillary tube with a $150 \mu \mathrm{M}$ diameter.

Caspase 3/7 assay. Following CAP treatment, the activities of Caspase-3 and Caspase-7 were measured using a specific substrate peptide coupled with a fluorescent dye (CellEvent ${ }^{\mathrm{TM}}$ Caspase-3/7 Green Detection Reagent; Thermo Fisher Scientific, Inc.) according to the manufacturer's protocol. Cells were incubated with CellEvent ${ }^{\mathrm{TM}}$ Caspase-3/7 Green Detection Reagent at $37^{\circ} \mathrm{C}$ for $45 \mathrm{~min}$. As a control, apoptosis was induced by the addition of cycloheximide $(15 \mu \mathrm{M}$ in cell culture medium; Carl Roth GmbH and Co. KG). Cells were incubated for $45 \mathrm{~min}$. at $37^{\circ} \mathrm{C}$. The fluorescent dye was then excited at $495 \mathrm{~nm}$, and the emission was measured at $535 \mathrm{~nm}$. Data were assessed using Infinite $200 \mathrm{PRO}$ and analyzed using i-control version 1.9 (Tecan Group, Ltd.).

Single-cell gel electrophoresis Comet assay. DNA damage after CAP treatment was identified using alkaline microgel electrophoresis (Comet assay). For measurements, cells were trypsinized directly after CAP treatment by incubating samples with $1 \mathrm{ml}$ trypsin/EDTA solution for 8-10 min. After neutralization with FCS (10\% v/v) and centrifugation (10 min; $900 \mathrm{U} / \mathrm{min} ; 161 \mathrm{x} \mathrm{g}$; room temperature), cell counting, and cell viability screening was performed using the Trypan blue exclusion test (26). Each slide was coated with $90 \mu 1$ $2 \times 10^{6}$ cells $/ \mathrm{ml}$ cell suspension, which were then covered with $400 \mu 10.5 \%$ LMT-Agarose UltraPure ${ }^{\mathrm{TM}}$ Low Melting Point Agarose (LMT-Agarose; Thermo Fisher Scientific, Inc.) and PBS mixed in ratio 5:1. The slides were subsequently placed in a gel electrophoresis chamber and incubated for $20 \mathrm{~min}$ with alkaline buffer solution containing $300 \mathrm{mM} \mathrm{NaOH}$ and $1 \mathrm{mM} \mathrm{Na}{ }_{2}$ EDTA (pH 10.0; room temperature). DNA was left to unwind, and subsequently, electrophoresis was performed at $25 \mathrm{~V}$ and $300 \mathrm{~mA}$ for $15 \mathrm{~min}$ at $4^{\circ} \mathrm{C}$. Neutralization was subsequently performed using $400 \mathrm{mM}$ Tris base, $\mathrm{pH} 7.5$ (Merck KGaA).

DNA staining was performed using ethidium bromide (Carl Roth $\mathrm{GmbH}$ ) for $10 \mathrm{~min}$ (room temperature) and analyzed using a BZ-9000 Fluorescent Microscope System (Keyence Corporation). DNA fragments in the tail were quantified via fluorescence microscopy 24 and $48 \mathrm{~h}$ after CAP treatment and digitized. DNA migration was measured using Comet Score Comet Assay IV (http://www.scorecomets. com/comet-scoring/comet-assay-iv) and defined as the percentage of DNA in the tail. The percentage of tail DNA was used to indicate the relative fluorescence intensity of the head and tail.

TUNEL assay. A total of $6 \times 10^{5} \mathrm{U} 2 \mathrm{OS}$ and MNNH/HOS cells were suspended in $500 \mu \mathrm{l}$ RPMI media (PAN Biotech GmbH). CAP treatment was performed according to the manufacturer's protocol based on the cell line used, as described above. After incubation for 24 and $48 \mathrm{~h}$, adherent cells were detached with $0.1 \%$ trypsin $/ 0.04 \%$ EDTA. TUNEL analysis was performed 

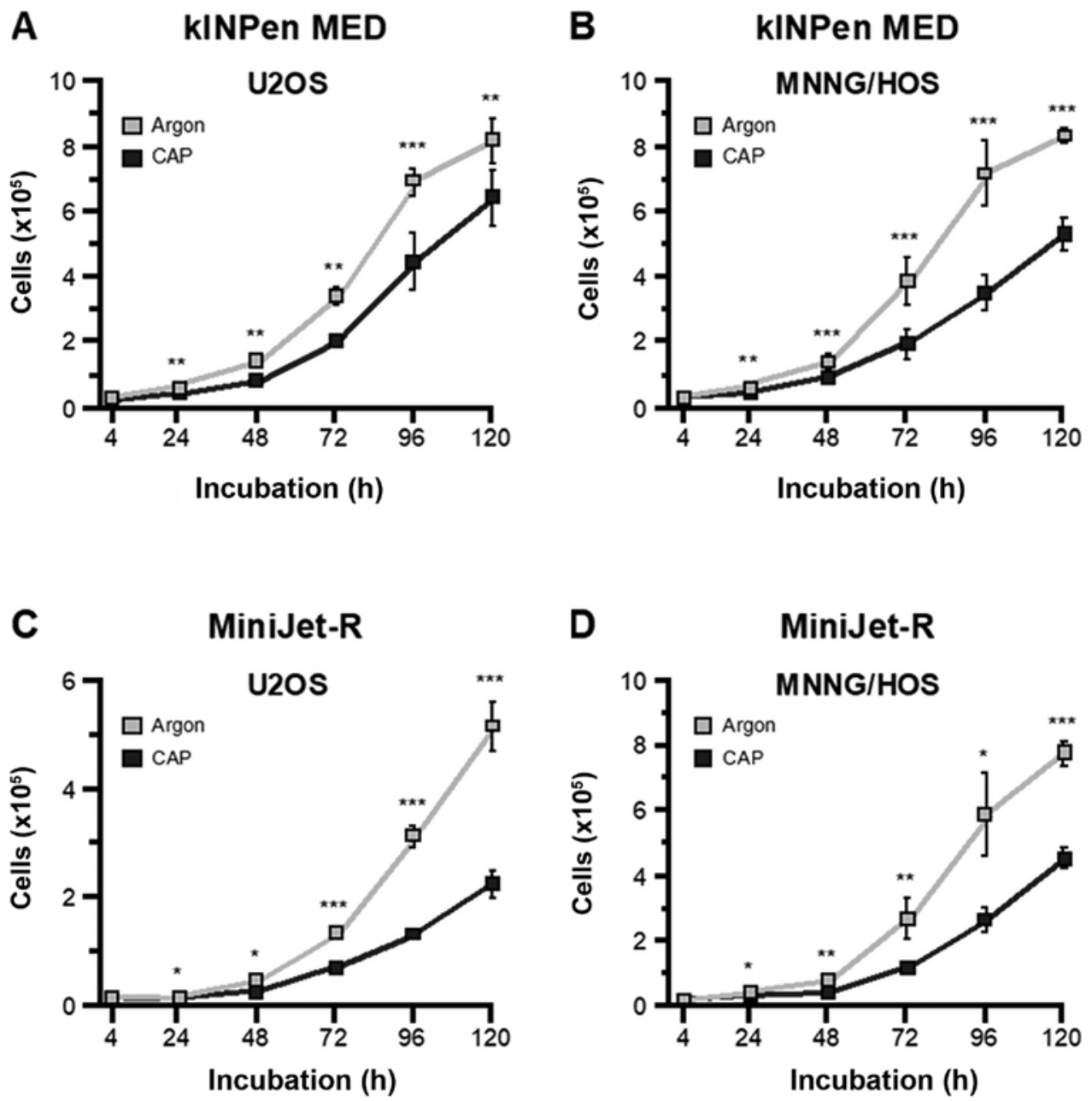

Figure 1. Growth inhibitory effects of CAP. The OS cell lines, MNNG-HOS and U2-OS, were treated with kINPen MED and MiniJet-R CAP sources, and compared with argon-treated control cells. Proliferation of the (A) U2OS and (B) MNNG/HOS cells treated with kINPen MED was significantly decreased $24 \mathrm{~h}$ after treatment and all time points assessed after that. Similar results were observed for the (C) U2OS and (D) MNNG/HOS cells treated with the MiniJet-R device. ${ }^{*} \mathrm{P} \leq 0.05,{ }^{* *} \mathrm{P} \leq 0.01,{ }^{* * *} \mathrm{P} \leq 0.001$. CAP, cold atmospheric plasma; OS, osteosarcoma.

using the HT TiterTACS Assay kit (Trevigen, Inc) according to the manufacturer's protocol. As a positive control, cells were nuclease treated according to the supplier's instruction (Trevigen, Inc). The incubation of the cells was at $37^{\circ} \mathrm{C}$ for $45 \mathrm{~min}$. Data were acquired using an Infinite 200 PRO multimode reader (Tecan Group, Ltd.) and analyzed using i-control version 1.9.

Statistical analysis. Statistical analysis was performed using GraphPad Prism version 5.01 (GraphPad Software, Inc.). For all experiments, two independent repeats with at least two technical replicates were performed. Data are presented as the mean and expressed as $\mathrm{x}$-fold expression. Comparisons were performed using a Student's t-test. $\mathrm{P} \leq 0.05$ was considered to indicate a statistically significant difference.

\section{Results}

Analysis of CAP-induced growth inhibition in an in vitro OS cell culture model. To investigate whether the biological effect of CAP was device dependent, two different CAP devices were used in the present study. OS cells were treated with the kINPen MED device for $10 \mathrm{sec}$ (U2-OS) and $20 \mathrm{sec}$ (MNNG-HOS). The results revealed that the growth kinetics over a 120 -h period were similar for both cell lines. Each cell line also exhibited significantly lower proliferation rates compared with argon treated control cells. However, this effect appeared to be more pronounced in MNNG/HOS cells (Fig. 1A and B). The same treatment was then applied using the MiniJet-R Cap source. Cell growth after CAP treatment was significantly lower compared with argon-treated control cells (Fig. 1A and B). To ensure comparability of the growth-inhibiting effects produced by the two devices, each cell line was treated with the MiniJet-R for $30 \mathrm{sec}$. The results revealed that CAP had a significant anti-proliferative effect during the 120-h incubation period (Fig. 1C and D).

CAP-induced activation of the apoptotic factors, Caspase- 3 and Caspase-7. Caspase- 3 and Caspase-7 are essential regulators of the apoptotic cascade. The activation of both enzymes was detected in the present study via a fluorogenic reaction. OS cells were treated for $10 \mathrm{sec}$ (U2-OS) and $20 \mathrm{sec}$ (MNNG-HOS) with the kINPen MED device and then treated for $30 \mathrm{sec}$ (U2-OS and MNNG-HOS) with the MiniJet-R device. Caspase-3/7 activation was subsequently measured after 24 and $48 \mathrm{~h}$. The results revealed that treatment with the KINPen MED device resulted in a significant 
A

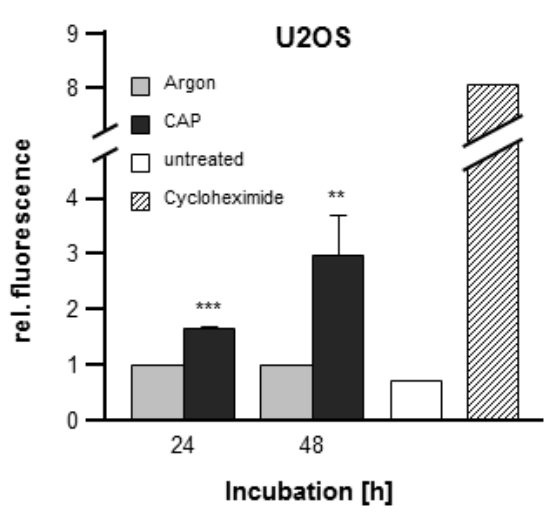

C

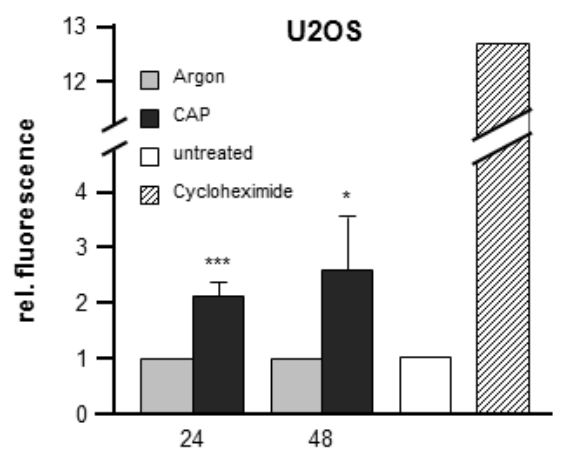

Incubation [h]

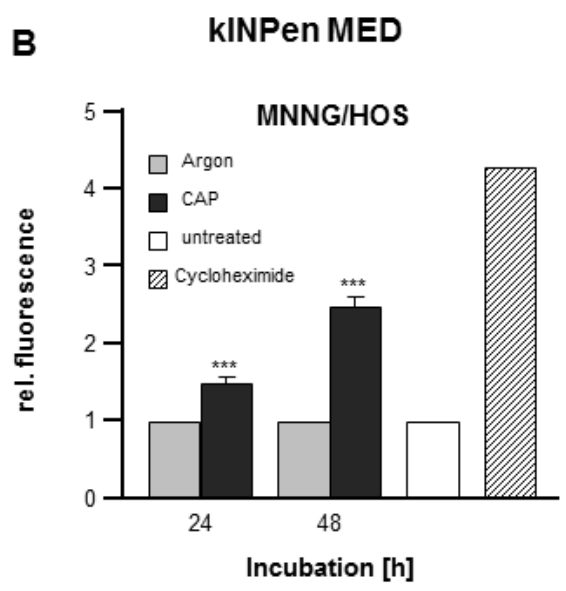

D

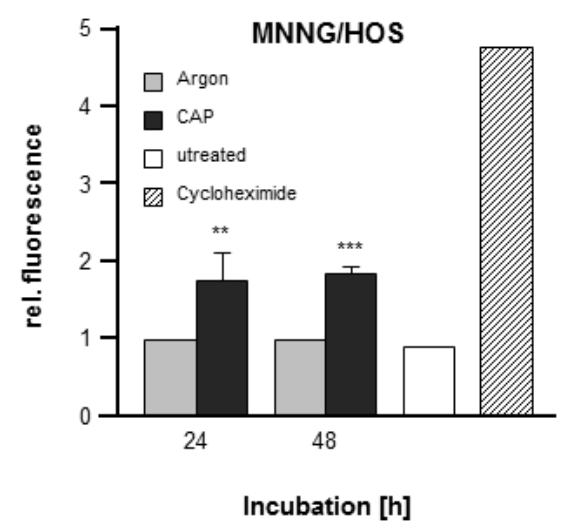

Figure 2. Caspase-3 and Caspase-7 activation in CAP treated cells. The OS cell lines, MNNG-HOS and U2-OS, were treated with kINPen MED and MiniJet-R CAP sources, and compared with argon-treated control cells. Cycloheximide served as positive control. The activation of Caspase-3 and Caspase-7 was determined after 24 and $48 \mathrm{~h}$ after CAP treatment in (A) U2OS and (B) MNNG/HOS cells treated with kINPen MED. Relative fluorescence (an indicator of Caspase activation) was significantly increased in both cell lines after 24 and $48 \mathrm{~h}$. Similar results were observed in the (C) U2OS and (D) MNNG/HOS cells treated with the MiniJet-R device. Data are presented as the mean \pm standard deviation. ${ }^{*} \mathrm{P} \leq 0.05,{ }^{* *} \mathrm{P} \leq 0.01,{ }^{* * *} \mathrm{P} \leq 0.001$. CAP, cold atmospheric plasma; OS, osteosarcoma.

induction of caspase-3/7 activity in U2-OS cells $(24 \mathrm{~h}$, 1.67-fold+0.04, $\mathrm{P}=0.0001 ; 48 \mathrm{~h}, 2.98$-fold+0.73, $\mathrm{P}=0.0096$ ) and MNNG-HOS cells (24 h, 1.50-fold+0.07, $\mathrm{P}=0.0004$; 48 h, 2.48-fold+0.12, P<0.0001; Fig. 2A and B, respectively). Incubation with the apoptosis inducer, cycloheximide, served as the positive control. Comparable results were obtained with the CAP source MiniJet-R. The apoptotic enzymes, Caspase-3 and 7, were both activated in U2-OS cells $(24 \mathrm{~h}$, 2.14-fold+0.23, $\mathrm{P}=0.0001 ; 48 \mathrm{~h}, 2.60$-fold $+0.94, \mathrm{P}=0.0250$ ) and in MNNG-HOS cells (24 h, 1.75-fold+0.37, $\mathrm{P}=0.0193$; 48 h, 1.84-fold+0.1, $\mathrm{P}=0.0005$; Fig. $2 \mathrm{C}$ and $\mathrm{D}$, respectively).

CAP-induced apoptotic DNA fragmentation, as detected using a Comet assay. In late apoptosis, genomic DNA is degraded, which can be detected microscopically in embedded cells. CAP treatment was performed with both devices as described above and analyzed 24 and $48 \mathrm{~h}$ later using a Comet assay. CAP treatment with the kINPen MED led to a significant increase in fragmented DNA in U2-OS cells after $24 \mathrm{~h}$ (Fig. 3A). However, in MNNG-HOS cells, the quantity of fragmented DNA decreased $24 \mathrm{~h}$ after CAP treatment (Fig. 3B). A similar result was observed with the MiniJet-R CAP source. A total of
$24 \mathrm{~h}$ after CAP treatment, an increase in fragmented DNA was detected in U2-OS cells (Fig. 3C), but the differences were not significant in MNNG-HOS cells (Fig. 3D). Additionally, $48 \mathrm{~h}$ after CAP treatment, neither of the approaches revealed a significant change in fragmented DNA.

CAP-induced apoptotic DNA fragmentation, as detected using the TUNEL assay. Due to the difficulty in interpreting data from the Comet assay, the same approach was repeated with both OS cell lines, both CAP sources and the same incubation time of 24 and $48 \mathrm{~h}$, using a TUNEL assay. Treatment with kINPenMED led to a significant increase in apoptotic DNA degradation products in U2-OS cells $(24 \mathrm{~h}, 2.00$-fold +0.09 , $\mathrm{P}=0.0098 ; 48 \mathrm{~h}, 1.51$-fold+0.22, $\mathrm{P}=0.0204$; Fig. 4A) as well as in MNNG-HOS cells (24 h, 1.64-fold $+0.11, \mathrm{P}=0.0003 ; 48 \mathrm{~h}$, 1.48-fold+0.31, P=0.0254; Fig. 4B) after each incubation time. Analysis conducted after CAP treatment with the MiniJet-R device confirmed these results, although the increase in DNA fragmentation in U2-OS cells after $24 \mathrm{~h}$ was not statistically significant (U2-OS: $24 \mathrm{~h}, 1.26$-fold+0.16, $\mathrm{P}=0.2416 ; 48 \mathrm{~h}$, 2.04-fold+0,35, $\mathrm{P}=0.0005$; MNNG-HOS: $24 \mathrm{~h}, 1.55$-fold +0.08 , $\mathrm{P}=0,0075 ; 48$ h, 1.34-fold+0.05, $\mathrm{P}=0.0008$; Fig. 4C and D). 

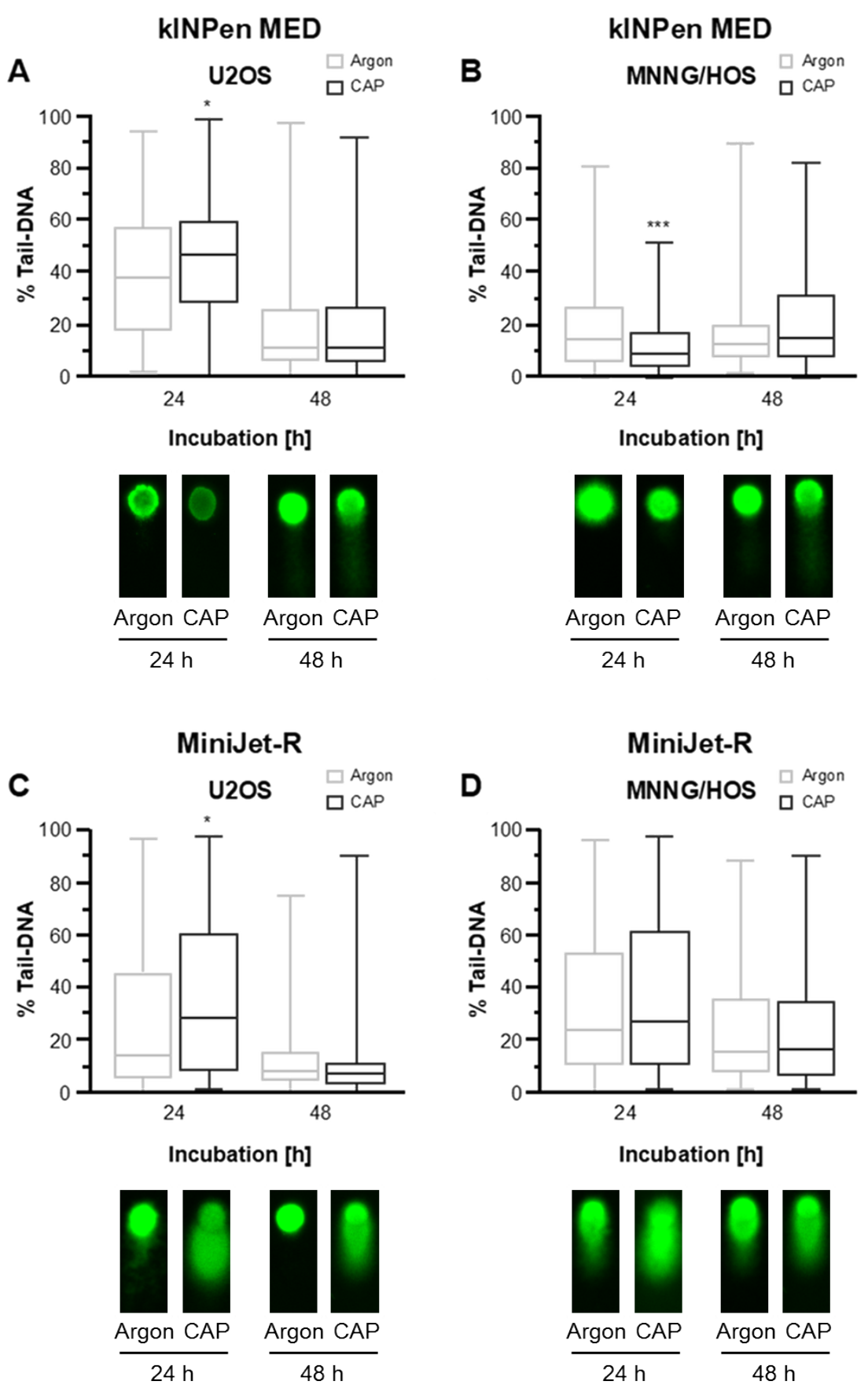

Figure 3. Comet assay detection of apoptotic DNA fragmentation following CAP treatment. The OS cell lines, MNNG-HOS and U2-OS, were treated with kINPen MED and MiniJet-R CAP sources, and compared with argon-treated control cells. DNA fragments in the tail were quantified via fluorescence microscopy 24 and $48 \mathrm{~h}$ after CAP treatment (upper panel) and representative images are shown (lower panel). The tail-length is positively associated with and indicative of apoptosis. (A) Tail length was significantly increased $24 \mathrm{~h}$ after treatment in the U2OS cells treated with kINPen MED although no difference was observed $48 \mathrm{~h}$ after treatment. (B) In the MNNG/HOS cells tail-length was decreased 24 after treatment with kINPen MED and no difference was seen after $48 \mathrm{~h}$. (C) Tail-length was significantly increased in the U2OS cells treated with the MiniJet-R device $24 \mathrm{~h}$ after treatment, and no difference was observed after $48 \mathrm{~h}$. (D) There was no difference in tail-length in the MNNG/HOS cells 24 or $48 \mathrm{~h}$ after treatment when treated with the MiniJet-R device. The percentage of DNA content is presented as the mean \pm standard deviation. Statistical evaluation was performed using a t-test. ${ }^{*} \mathrm{P} \leq 0.05,{ }^{* * *} \mathrm{P} \leq 0.001$. CAP, cold atmospheric plasma; OS, osteosarcoma.

\section{Discussion}

In addition to the other application areas of CAP, such as the disinfection of wounds and treatment of atopic eczema or chronic wounds (27-29), oncological use has been promoted for a number of years (30-33). Aside from its efficacy as an antiseptic, the anti-proliferative effects of CAP have been demonstrated (34-36). The aim of the present study was to investigate the anticancer properties of a plasma jet device, the MiniJet-R, which has thus far only been used exclusively for technical applications. The biological effects of the MiniJet-R were very similar to those of the well-characterized kINPenMED device $(18,19,25,37)$. Only a slightly longer treatment time $(30 \mathrm{sec})$ is required to yield comparable 
A

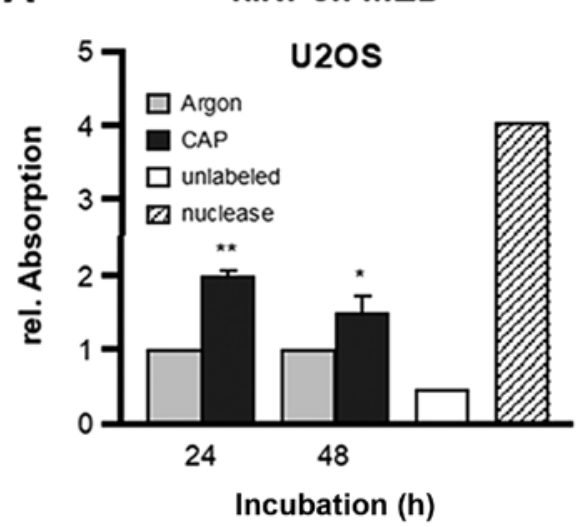

C

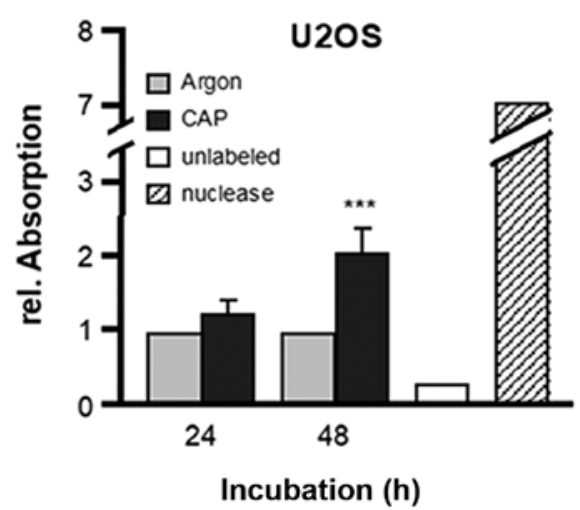

B

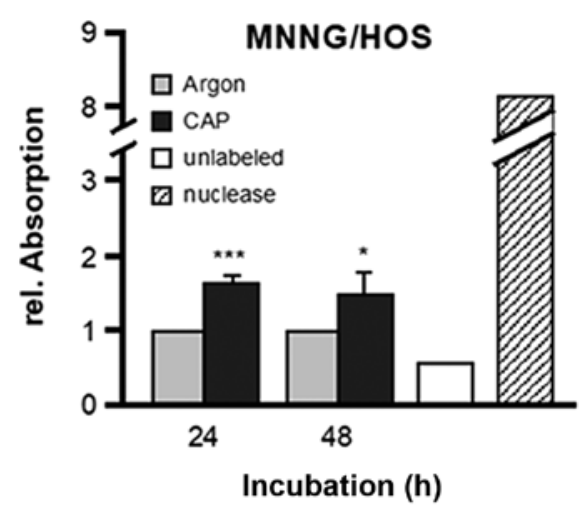

D

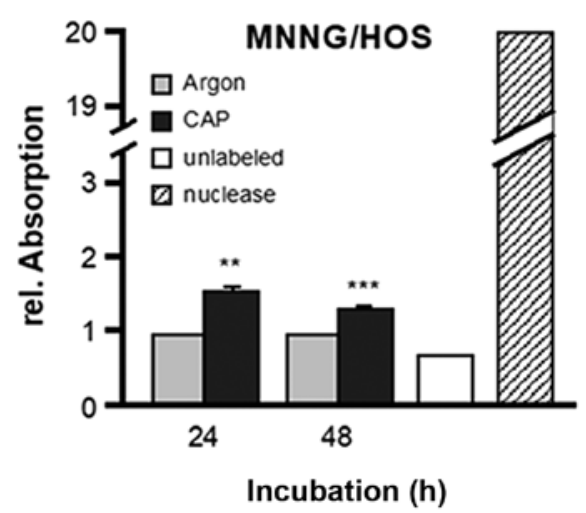

Figure 4. Detection of apoptotic DNA fragmentation after CAP treatment using a TUNEL assay. The OS cell lines, MNNG-HOS and U2-OS, were treated with kINPen MED and MiniJet-R CAP sources, and compared with argon-treated control cells. Free DNA ends were quantified 24 and $48 \mathrm{~h}$ after CAP treatment and expressed as the relative mean \pm standard deviation. An increase in relative absorption was indicative of increased apoptosis. Apoptosis was significantly increased in (A) U2OS and (B) MNNG/HOS cells treated with kINPen MED 24 and $48 \mathrm{~h}$ after treatment. Apoptosis was increased in the (C) U2OS cells $48 \mathrm{~h}$ after treatment and (D) MNNG/HOS cells 24 and $48 \mathrm{~h}$ after treatment with the MiniJet-R device. ${ }^{*} \mathrm{P} \leq 0.05,{ }^{* *} \mathrm{P} \leq 0.01$ and ${ }^{* * * *} \mathrm{P} \leq 0.001$. CAP, cold atmospheric plasma; OS, osteosarcoma.

anti-proliferative and pro-apoptotic effects. This confirmed that the biological properties of CAP are essentially determined by the CAP source, which makes a direct comparison of two different sources very difficult $(38,39)$. The most important technical difference between the two argon CAP devices, kINPen MED and MiniJet-R, is the frequency range in which CAP is generated. Whereas the kINPen MED operates in the radio frequency range $(1 \mathrm{MHz})$, the MiniJet-R generates $\mathrm{CAP}$ in the microwave frequency range $(2.41 \mathrm{GHz})(33)$. The excitation frequency significantly influences the density and composition of reactive molecular species and thus, the biological efficacy of CAP $(36,40)$. However, a previous study that utilized three CAP devices, including the kINPen MED, revealed that the anti-cancer properties and required treatment times were very similar (35). Furthermore, although different OS cell lines may also have different sensitivities to CAP treatment, previous experimental approaches have demonstrated comparable treatment parameters, leading to similar biological effects $(18,22)$. When evaluating CAP efficacy, it must also be taken into account that even cell lines of similar malignant profiles may react differently to chemically or physically noxious agents. This has also been demonstrated for CAP treatment. For example, it was shown that different ovarian cancer cell lines, glioblastoma and osteosarcoma had to be treated for different times in order to achieve similar cell responses $(20,21,41)$. Additionally, the same treatment in MNNG and U2-OS cells led to the activation of different cytokine patterns (25).

In the present study, $24 \mathrm{~h}$ after treatment, no increase in apoptotic DNA degradation was detectable in a comet assay. The results revealed a significantly decreased comet-specific signal. Furthermore, since no significant induction of apoptosis was observed in the comet assay $48 \mathrm{~h}$ after treatment, measuring apoptosis was deemed unsuitable or lacking in sensitivity to determine the effects of CAP. In various cancer cells, it has been demonstrated that CAP treatment induces apoptosis, which is the most significant anti-proliferative effect $(15,33)$. Initial in vitro studies with CAP-treated OS cells have also indicated induction of apoptosis. However, only the induction and activation of p53, as well as pyknotic changes in nuclear morphology after CAP treatment have been demonstrated (18). The involvement of apoptotic processes as an essential mechanism of the anti-proliferative effects of CAP was demonstrated in the present study. Treatment with the kINPen MED and the MiniJet-R device led to the activation of caspases-3/7, followed by the apoptotic degradation of genomic DNA. The initial 
upstream regulation of apoptotic cascades has not yet been fully examined. It has been hypothesized that the increase in reactive oxygen and nitrogen species (RONS) induced by CAP treatment mediates apoptosis $(15,42)$. In the presence of the $\mathrm{N}$-acetylcysteine RONS scavenger, the anti-proliferative effect of CAP was partially neutralized (43). In addition, it has been revealed that peroxiredoxins, as regulatory factors of the redox system, are involved in the CAP-induced cell response (15). Furthermore, p53, mitogen-activated kinases and other kinases have been identified as CAP-modulated factors (18,43-45). Direct DNA damage caused by RONS has also been evaluated by oxidation processes on the DNA or by strand breaks (46). However, CAP has been revealed to result in DNA damage in certain living cells; therefore, additional studies are required to determine the clinical potential of CAP (47-49).

CAP treatment of the two OS cell lines assessed in the present study led to induction of apoptosis according to the TUNEL and caspase assays, which may represent the most important anti-proliferative effect of CAP treatment. CAP treatment of the OS cell lines, MNNG-HOS and U2-OS, resulted in decreased cell growth, activation of Caspase-3/7 and degradation of genomic DNA. These biological effects exhibited no substantial differences between the two CAP sources, MiniJet-R and kINPen MED. Regarding potential clinical use, it can be stated that the CAP source, MiniJet-R, as well as the approved CAP source, kINPen MED, appear to be suitable for use as an anti-OS therapy. As with all translational experimental approaches, in vivo studies are necessary to determine whether the effects demonstrated in vitro are detectable in clinical applications and to elucidate their role in patient treatment.

\section{Acknowledgements}

The authors would like to thank Mrs. Katja Witting, technical assistant of the Department of Urology (University Medicine Greifswald, Greifswald, Germany) for her excellent technical assistance.

\section{Funding}

The present study was financed from planned funds for scientific research of the University Medicine Greifswald (Greifswald, Germany; grant. no. URO-FO+LE 97250000).

\section{Availability of data and materials}

The datasets used and/or analyzed during the present study are available from the corresponding author on reasonable request.

\section{Authors' contributions}

LH, SB, JL, MBS prepared and edited the manuscript; LH, DG and MBS conceived the study design. LW and NG performed the experiments; LH, SB, JL, AK and MBS performed data analysis; and $\mathrm{AE}, \mathrm{MB}$ and $\mathrm{AK}$ supervised the project.

\section{Ethics approval and consent to participate}

Not applicable.

\section{Patient consent for publication}

Not applicable.

\section{Competing interests}

The authors declare that they have no competing interests.

\section{References}

1. Savage SA and Mirabello L: Using epidemiology and genomics to understand osteosarcoma etiology. Sarcoma 2011: 548151, 2011.

2. Zhao H, Yao Y, Wang Z, Lin F, Sun Y and Chen P: Therapeutic effect of pirarubicin-based chemotherapy for osteosarcoma patients with lung metastasis. J Chemother 22: 2, 119-124, 2010.

3. He A, Yang X, Huang Y, Feng T, Wang Y, Sun Y, Shen Z and Yao Y: CD133(+) CD44(+) cells mediate in the lung metastasis of osteosarcoma. J Cell Biochem 116: 1719-1729, 2015.

4. Tang N, Song WX, Luo J, Haydon RC and He TC: Osteosarcoma development and stem cell differentiation. Clin Orthop Relat Res 466: 2114-2130, 2008.

5. Daw NC, Chou AJ, Jaffe N, Rao BN, Billups CA, Rodriguez-Galindo C, Meyers PA and Huh WW: Recurrent osteosarcoma with a single pulmonary metastasis: A multi-institutional review. Br J Cancer 112: 278-282, 2015.

6. Marina N, Gebhardt M, Teot L and Gorlick R: Biology and therapeutic advances for pediatric osteosarcoma. Oncologist 9: 422-441, 2004

7. Salunke AA, Chen Y, Tan JH, Chen X, Khin LW and Puhaindran ME: Does a pathological fracture affect the prognosis in patients with osteosarcoma of the extremities?: A systematic review and meta-analysis. Bone Joint J 96-B: 1396-1403, 2014.

8. Munajat I, Zulmi W, Norazman MZ and Wan Faisham WI: Tumour volume and lung metastasis in patients with osteosarcoma. J Orthop Surg (Hong Kong) 16: 182-185, 2008.

9. Liu Y, Xu Y, Lin N, Jiang S, Wang Y and Ye Z: High-dose methotrexate (HD-MTX) used as an adjunct with other chemotherapeutics for the treatment of osteosarcoma. Cell Biochem Biophys 71: 1097-1104, 2015.

10. Yu W, Tang L, Lin F, Yao Y, Shen Z and Zhou X: High-intensity focused ultrasound: Noninvasive treatment for local unresectable recurrence of osteosarcoma. Surg Oncol 24: 9-15, 2015.

11. Faisham WI, Mat Saad AZ, Alsaigh LN, Nor Azman MZ, Kamarul Imran M, Biswal BM, Bhavaraju VM, Salzihan MS, Hasnan J, Ezane AM, et al: Prognostic factors and survival rate of osteosarcoma: A single-institution study. Asia Pac J Clin Oncol 13: e104-e110, 2017.

12. Fu HL, Shao L, Wang Q, Jia T, Li M and Yang DP: A systematic review of p53 as a biomarker of survival in patients with osteosarcoma. Tumor Biol 34: 3817-3821, 2013.

13. Luetke A, Meyers PA, Lewis I and Juergens H: Osteosarcoma treatment-Where do we stand? A state of the art review. Cancer Treat Rev 40: 523-532, 2014.

14. Lendeckel D, Eymann C, Emicke P, Daeschlein G, Darm K, O'Neil S, Beule AG, von Woedtke T, Völker U, Weltmann KD, et al: Proteomic Changes of Tissue-tolerable plasma treated airway epithelial cells and their relation to wound healing. Biomed Res Int 2015: 506059, 2015.

15. Weiss M, Gümbel D, Hanschmann EM, Mandelkow R, Gelbrich N, Zimmermann U, Walther R, Ekkernkamp A, Sckell A, Kramer A, et al: Cold atmospheric plasma treatment induces anti-proliferative effects in prostate cancer cells by redox and apoptotic signaling pathways. PLoS One 10: e0130350, 2015

16. Reiazi R, Akbari ME, Norozi A and Etedadialiabadi M: Application of cold atmospheric plasma (cap) in cancer therapy: A review. Int J Cancer Manag 10: e8728, 2017.

17. Chen Z, Lin L, Zheng Q, Sherman JS, Canady J, Trink B and Keidar M: Micro-sized cold atmospheric plasma source for brain and breast cancer treatment. Plasma Med 8: 203-211, 2018.

18. Gümbel D, Gelbrich N, Weiss M, Napp M, Daeschlein G, Sckell A, Ender SA, Kramer A, Burchardt M, Ekkernkamp A and Stope MB: New treatment options for osteosarcoma-inactivation of osteosarcoma cells by cold atmospheric plasma. Anticancer Res 36: 5915-5922, 2016. 
19. Gümbel D, Gelbrich N, Napp M, Daeschlein G, Kramer A Sckell A, Burchardt M, Ekkernkamp A and Stope MB: Peroxiredoxin expression of human osteosarcoma cells is influenced by cold atmospheric plasma treatment. Anticancer Res 37 1031-1038, 2017.

20. Koensgen D, Besic I, Gümbel D, Kaul A, Weiss M, Diesing K, Kramer A, Bekeschus S, Mustea A and Stope MB: Cold atmospheric plasma (CAP) and CAP-stimulated cell culture media suppress ovarian cancer cell growth-a putative treatment option in ovarian cancer therapy. Anticancer Res 37: 6739-6744, 2017.

21. Gümbel D, Bekeschus S, Gelbrich N, Napp M, Ekkernkamp A Kramer A and Stope MB: Cold atmospheric plasma in the treatment of osteosarcoma. Int J Mol Sci 18: pii: E2004, 2017.

22. Gümbel D, Daeschlein G, Ekkernkamp A, Kramer A and Stope MB: Cold atmospheric plasma in orthopaedic and urologic tumor therapy. GMS Hyg Infect Control 12: Doc10, 2017.

23. Weiss M, Daeschlein G, Kramer A, Burchardt M, Brucker S, Wallwiener D and Stope MB: Virucide properties of cold atmospheric plasma for future clinical applications. J Med Virol 89: 952-959, 2017.

24. Schmidt A, Bekeschus S, von Woedtke T and Hasse S: Cell migration and adhesion of a human melanoma cell line is decreased by cold plasma treatment. Clin Plasma Med 3: 24-31, 2015.

25. Haralambiev L, Wien L, Gelbrich N, Kramer A, Mustea A, Burchardt M, Ekkernkamp A, Stope MB and Gümbel D: Effects of cold atmospheric plasma on the expression of chemokines, growth factors, TNF superfamily members, interleukins, and cytokines in human osteosarcoma cells. Anticancer Res 39: 151-157, 2019.

26. Strober W: Trypan blue exclusion test of cell viability. Curr Protoc Immunol 111: A3.B.1-3, 2015.

27. Daeschlein G, Scholz S, Arnold A, von Podewils S, Haase H, Emmert S, von Woedtke T, Weltmann KD and Juenger $M$ : In vitro susceptibility of important skin and wound pathogens against low temperature atmospheric pressure plasma jet (APPJ) and dielectric barrier discharge plasma (DBD). Plasma Processes Polymers 9: 380-389, 2012

28. Assadian O, Ousey KJ, Daeschlein G, Kramer A, Parker C, Tanner $\mathbf{J}$ and Leaper DJ: Effects and safety of atmospheric low-temperature plasma on bacterial reduction in chronic wounds and wound size reduction: A systematic review and meta-analysis. Int Wound J 16: 103-111, 2019.

29. Bernhardt T, Semmler ML, Schäfer M, Bekeschus S, Emmert S and Boeckmann L: Plasma medicine: Applications of cold atmospheric pressure plasma in dermatology. Oxid Med Cell Longev 2019: 3873928, 2019.

30. Lunov O, Zablotskii V, Churpita O, Chánová E, Syková E, Dejneka A and Kubinová S: Cell death induced by ozone and various non-thermal plasmas: Therapeutic perspectives and limitations. Sci Rep 4: 7129, 2014.

31. Vandamme M, Robert E, Lerondel S, Sarron V, Ries D, Dozias S, Sobilo J, Gosset D, Kieda C, Legrain B, et al: ROS implication in a new antitumor strategy based on non-thermal plasma. Int J Cancer 130: 2185-2194, 2012.

32. Graves DB: Reactive species from cold atmospheric plasma: Implications for cancer therapy. Plasma Process Polym 11: 1120-1127, 2014

33. Hirst AM, Simms MS, Mann VM, Maitland NJ, O'Connell D and Frame FM: Low-temperature plasma treatment induces DNA damage leading to necrotic cell death in primary prostate epithelial cells. Br J Cancer 112: 1536-1545, 2015.

34. Weiss M, Gümbel D, Gelbrich N, Brandenburg LO, Mandelkow R, Zimmermann U,Ziegler P, Burchardt M and Stope MB: Inhibition of cell growth of the prostate cancer cell model LNCaP by Cold Atmospheric Plasma. In Vivo 29: 611-116, 2015.
35. Binenbaum Y, Ben-David G, Gil Z, Slutsker YZ, Ryzhkov MA, Felsteiner J, Krasik YE and Cohen JT: Cold atmospheric plasma, created at the tip of an elongated flexible capillary using low electric current, can slow the progression of Melanoma. PLoS One 12: e0169457, 2017

36. Hattori N, Yamada S, Torii K, Takeda S, Nakamura K, Tanaka H, Kajiyama H, Kanda M, Fujii T, Nakayama G, et al: Effectiveness of plasma treatment on pancreatic cancer cells. Int J Oncol 47: $1655-1662,2015$.

37. Gümbel D, Suchy B, Wien L, Gelbrich N, Napp M, Kramer A, Ekkernkamp A, Daeschlein G and Stope MB: Comparison of cold atmospheric plasma Devices' efficacy on osteosarcoma and fibroblastic in vitro cell models. Anticancer Res 37: 5407-5414, 2017.

38. Winter J, Brandenburg R and Weltmann KD: Atmospheric pressure plasma jets: An overview of devices and new directions. Plasma Sources Sci Technol 24: 19, 2015.

39. Laroussi M and Akan T: Arc-free atmospheric pressure cold plasma jets: A review. Plasma Process Polym 4: 777-788, 2007.

40. Schmidt-Bleker A, Bansemer R, Reuter S and Weltmann KD: How to produce an NOx-instead of Ox-based chemistry with a cold atmospheric plasma jet. Plasma Process Polym 13: 120-1127, 2016.

41. Siu A, Volotskova O, Cheng X, Khalsa SS, Bian K, Murad F, Keidar M and Sherman JH: Differential effects of cold atmospheric plasma in the treatment of malignant glioma. PLoS One 10: e0126313, 2015.

42. Nguyen NH, Park HJ, Yang SS, Choi KS and Lee JS: Anti-cancer efficacy of nonthermal plasma dissolved in a liquid, liquid plasma in heterogeneous cancer cells. Sci Rep 6: 29020, 2016

43. Ishaq M, Kumar S, Varinli H, Han ZJ, Rider AE, Evans MD, Murphy AB and Ostrikov K: Atmospheric gas plasma-induced ROS production activates TNF-ASK1 pathway for the induction of melanoma cancer cell apoptosis. Mol Biol Cell 25: 1523-1531, 2014.

44. Ma Y, Ha CS, Hwang SW, Lee HJ, Kim GC, Lee KW and Song K: Non-thermal atmospheric pressure plasma preferentially induces apoptosis in p53-mutated cancer cells by activating ROS stress-response pathways. PLoS One 9: e91947, 2014.

45. Kang SU, Cho JH, Chang JW, Shin YS, Kim KI, Park JK, Yang SS, Lee JS, Moon E, Lee K and Kim CH: Nonthermal plasma induces head and neck cancer cell death: The potential involvement of mitogen-activated protein kinase-dependent mitochondrial reactive oxygen species. Cell Death Dis 5: e1056, 2014.

46. Arjunan KP, Sharma VK and Ptasinska S: Effects of atmospheric pressure plasmas on isolated and cellular DNA-a review. Int J Mol Sci 16: 2971-3016, 2015.

47. Kluge S, Bekeschus S, Bender C, Benkhai H, Sckell A, Below H, Stope MB and Kramer A: Investigating the mutagenicity of a cold argon-plasma jet in an HET-MN Model. PLoS One 11: e0160667, 2016.

48. Strassenburg S, Greim U, Bussiahn R, Haertel B, Wende K, Woedtke $\mathrm{T}$ and Lindequist $\mathrm{U}$ : Comparison of biological effects on human keratinocytes using different plasma treatment regimes. Plasma Med 3: 57-69, 2013.

49. Bekeschus S, Schütz CS, Nießner F, Wende K, Weltmann KD, Gelbrich N, Woedtke T, Schmidt A and Stope MB: Elevated $\mathrm{H} 2 \mathrm{AX}$ phosphorylation observed with kINPen plasma treatment is not caused by ROS-mediated DNA damage but is the consequence of apoptosis. Oxid Med Cell Longev 2019: 8535163, 2019.

This work is licensed under a Creative Commons Attribution-NonCommercial-NoDerivatives 4.0 International (CC BY-NC-ND 4.0) License. 